\title{
Genetic variation in East-Adriatic populations of the Asian tiger mosquito, Aedes albopictus (Diptera: Culicidae), inferred from $\mathrm{NADH5}$ and $C O I$ sequence variability
}

\author{
TonI ŽITKO ${ }^{1}$, ANA KOVAČIĆ ${ }^{1}$, Yves DESDEVISES ${ }^{2}$ and JASNA PUIZINA ${ }^{3 *}$ \\ ${ }^{1}$ Public Health Institute of Split and Dalmatia County, Vukovarska 46, 21000 Split, Croatia \\ ${ }^{2}$ UPMC Univ. Paris 06, UMR 7232, Biologie Intégrative des Organismes Marins, Observatoire Océanologique, \\ F-66650, Banyuls/Mer, France \\ ${ }^{3}$ University of Split, Faculty of Science, Department of Biology, Teslina 12, 21000 Split, Croatia
}

Key words. Diptera, Culicidae, Aedes albopictus, Asian tiger mosquito, cytochrome oxidase I (COI), NADH dehydrogenase 5 (ND5), biological invasion

\begin{abstract}
In the last few decades, Aedes albopictus (Skuse) (Diptera: Culicidae) (= Stegomyia albopicta), the so-called "Asian tiger mosquito", has spread from its native range in southeast Asia to Africa, the Middle East, Europe, the Americas, and Pacific islands. The spread of this species poses a risk to human health as it is considered to be one of the main vectors of dengue and other arboviruses. Aedes albopictus was reported in Croatia in 2004, thereafter it was discovered at several coastal localities in 2005 and to date it has spread to most coastal areas and islands in Croatia. Here we investigate the genetic variability of A. albopictus based on 39 individuals collected during the summer of 2009 along the East-Adriatic coast and islands of Croatia and Montenegro and using two mitochondrial molecular markers: cytochrome oxidase I (COI) and NADH dehydrogenase 5 (ND5). We identified a single ND5 haplotype, corresponding to the previously reported and worldwide-distributed haplotype H3. The COI marker was more variable and we identified four $C O I$ haplotypes. In order to identify the geographic origin of the populations that colonized Croatia, we performed phylogenetic analyses of ND5 and COI haplotypes in Croatian populations and other A. albopictus populations retrieved from the GenBank. The phylogenetic tree based on ND5 haplotypes revealed two well supported clades where the unique Croatian ND5 haplotype clustered with the majority of haplotypes originating from South-Asia, America, Europe, and Africa. Another smaller cluster consisted of only Brazilian haplotypes. The phylogenetic tree and haplotype network that resulted from the COI analysis also indicates that the three Croatian COI haplotypes cluster with European and American haplotypes. However the fourth Croatian COI haplotype was the only European haplotype that occurred in a separate clade (group) with Indian, South-Asian, and Brazilian haplotypes. This data suggests there have been several independent introduction events in Croatia.
\end{abstract}

\section{INTRODUCTION}

In the last few decades, Aedes albopictus (Skuse) (Diptera: Culicidae) (= Stegomyia albopicta) (Reinert \& Harbach, 2005), the so-called "Asian tiger mosquito", has spread from its native range in southeast Asia to different parts of Africa, the Middle East, Europe, the Americas, and some Pacific islands (Gratz, 2004). The invasion of this species poses a risk to human health. Besides the nuisance caused by $A$. albopictus biting activity, it is a maintenance vector (occasionally epidemic) of dengue viruses in some parts of Asia (CDC, 2005) and plays an important role in the transmission of several other arboviruses, including chikungunya on the island of La Réunion (Reiter et al., 2006) and in Italy (Beltrame et al., 2007), eastern equine encephalitis (Mitchell et al., 1992), LaCrosse encephalitis (Gerhardt et al., 2001), Bunyaviridae (Francy et al., 1990), West Nile virus (Turell et al., 2001) and Dirofilaria spp. (Gratz, 2004). The first two cases of local dengue transmission in Europe were reported from Nice, southeast France, in 2010 (La Ruche, 2010). The same year, another autochthonous dengue transmission occurred via a traveller from Germany returning from a trip to southern Croatia (SchmidtChanasit et al., 2010). It indicates that autochthonous transmission of dengue is also possible in the other parts of Europe where $A$. albopictus is established (La Ruche et al., 2010).

The usual way of dispersal of this invasive species is the transport of its eggs in used tires (Knudsen, 1995), so A. albopictus has been able to travel across very large distances and even between continents mainly via the international used tire trade (Reiter, 1998). Nevertheless, the international trade of a decorative plant, the Lucky Bamboo (Dracaena spp.), is also thought to have been important in the spread of this species (Madon et al., 2003). Due to its ability to colonize a wide range of natural and artificial breeding places together with the resistance of its eggs to desiccation and its relative lack of host specificity (Hawley, 1988), this species has been able to rapidly build up large stable populations in new geographic regions. Once established in a new area national trade and traffic has facilitated the subsequent rapid spread of this mosquito into other areas (Moore \& Mitchell, 1997).

\footnotetext{
* Corresponding author; e-mail:puizina@pmfst.hr
} 
Prior to 1985 , it was known that A. albopictus was present from Madagascar, southern Asia northward to Beijing, China, Seoul, Korea, and Sendai, Japan (Hawley, 1988). Aedes albopictus was also established in Hawai'i, Guam, Indonesia, West Papua, Papua New Guinea and Solomon Islands eastward to Santa Cruz Island (Mitchell, 1995). In 1985 its presence was reported in the USA where it was probably arrived in tire shipments from Northern Asia (Hawley et al., 1987). This species is also spreading across the Pacific islands of Palau, Yap and Fiji (CDC, 2005) and Torres Strait Islands in Australia (Ritchie et al., 2006). Established populations of $A$. albopictus were detected in Brazil in 1986. This species colonized Mexico in 1988 and thereafter many countries of Central and South America: Argentina, Bolivia, Cuba, Honduras, Guatemala, El Salvador, Colombia, Cayman Islands (Rossi et al., 1999; CDC, 2005) and also some parts of Paraguay, Panama, Uruguay and Nicaragua (Cuéllar-Jiménez et al., 2007). In Africa, A. albopictus was discovered in Nigeria in 1991 and then spread to Cameroon (Fontenille \& Toto, 2001), Bioko Island of Equatorial Guinea and Gabon (Toto et al., 2003; Krueger \& Hagen, 2007). In the Middle East $A$. albopictus is present in Israel (Pener et al., 2003), Lebanon and Syria (Haddad et al., 2007).

In Europe, after the first detection of A. albopictus in Albania in 1979 (Adhami \& Reiter, 1998), this species was found in Genoa in September 1990 and Padua in 1991 with a suggestion that latter introduction could have resulted from tire imports from the United States (Sabatini et al., 1990; Dalla Pozza \& Majori, 1992; Dalla Pozza et al., 1994). Since then A. albopictus has spread throughout the entire mainland of Italy as well as some parts of Sicily and Sardinia. Apart from Albania and Italy, established homogenous populations of A. albopictus occur in Croatia, France, Greece, Monaco, Montenegro, San Marino, Slovenia, Spain and Vatican City (ECDC, 2008). Aedes albopictus is recorded as occurring in Germany but it is unknown whether it has established there (Pluskota et al., 2008). It has also been introduced into Belgium (Schaffner et al., 2004), but it has not established there (ECDC, 2008). In the Netherlands, it is recorded only inside greenhouses (Scholten et al., 2007; ECDC, 2008). In southern Switzerland, recent data suggest an ongoing spread (Flacio et al., 2004; ECDC, 2008). It has also been reported from isolated foci in Bosnia and Herzegovina, but no further details are available (ECDC, 2008).

Aedes albopictus was reported in Croatia in 2004 (Klobučar et al., 2006), thereafter it was discovered at several coastal localities in 2005 and to date it has spread to most coastal areas and islands in Croatia (Merdić et al., 2009). Little is known about the role of European $A$. albopictus in the pathogenesis of different diseases. In order to obtain a better understanding of the introduction, spread, evolution and local adaptation of $A$. albopictus it is necessary to study its genetic structure (ECDC, 2008).

The aims of this study were: (1) to determine the pattern of genetic variation within the Croatian $A$. albopictus

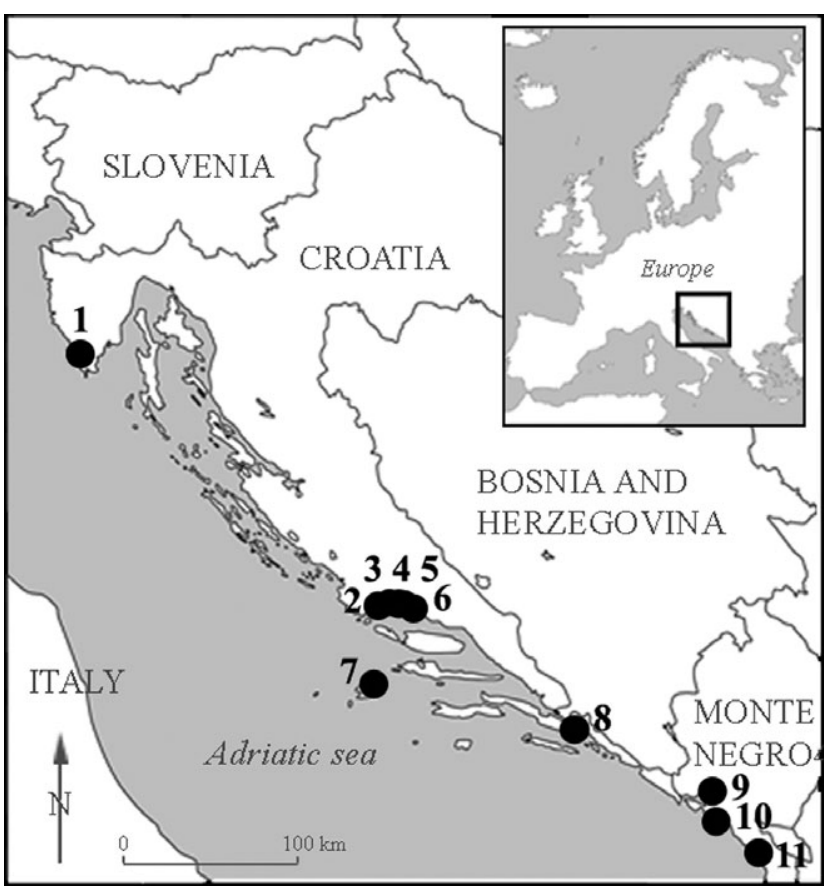

Fig. 1. Sites (numbered 1-11; see Table 1) at which the Asian tiger mosquito (Aedes albopictus) was sampled.

population based on analyses of the sequence diversity of two mitochondrial genes, cytochrome oxidase I (COI) and the NADH dehydrogenase subunit 5 (ND5); and (2) to establish the evolutionary relationships of the Croatian population with other $A$. albopictus populations and determine the geographic origin of the populations that colonized Croatia.

\section{MATERIAL AND METHODS}

\section{Sampling}

We examined 39 specimens of Aedes albopictus collected at 11 locations along the East Adriatic Coast in September and October 2009 (Fig. 1; Table 1). Adult mosquitoes were captured with aspirators at eight locations on the Adriatic Coast of Croatia and their eggs collected using ovitraps at three locations on the Adriatic Coast of Montenegro (Fig. 1; Table 1). The eggs were hatched and the larvae reared to adults in the laboratory. Adult mosquitoes were identified based on their morphology and using a key (Becker et al., 2003). All samples were placed in plastic tubes with $80 \%$ ethanol until further processing.

\section{DNA extraction, amplification and sequencing}

Prior to DNA extraction samples were thoroughly washed with $95 \%$ ethanol and left to dry in the air. Specimens were ground and DNA extraction was performed using a commercial kit for DNA isolation (Qiagen DNeasy Blood \& Tissue kit, Hilden, Germany) according to the manufacturer's instructions. Two mitochondrial regions extracted from Aedes albopictus DNA were amplified, cytochrome oxidase I (COI) and NADH dehydrogenase 5 subunit (ND5). PCR amplification of the COI subunit was first performed using the primers used by Mousson et al. (2005), 5' TGATCAAATTTATAAT 3' (COIF) and 5' GGTAAAATTAAAATATAAACTTC 3' (COIR), but no DNA was amplified. The analysis using a different set of primers (Patsoula et al., 2006) was successful; these primers were 5'-CGAGGATTTGGAAATTGATTAGTTC-3' (COI2F) and 5'-CCCGGTAAAATTAAAATATAAACTTC-3' (COI2R). In 
TABLE 1. Sites sampled and data on the specimens collected. The four COI haplotypes, Cro1-Cro4, are identified. All the individuals analyzed had the unique ND5 haplotype.

\begin{tabular}{clccc}
\hline Sites sampled & Country / Locality & $\begin{array}{c}\text { COI haplotypes, GenBank accession } \\
\text { numbers (no. of individuals) }\end{array}$ & Date of collection & Stage of mosquito collected \\
\hline & Croatia & $\begin{array}{c}\text { Cro1, HQ906848 (11) } \\
\text { Cro4, HQ906851 (1) }\end{array}$ & Oct 2009 & Adult \\
\hline 1 & Pula & Cro1, HQ906848 (1) & Sep 2009 & Adult \\
\hline 2 & Trogir & Cro1, HQ906848 (3) & Sep 2009 & Adult \\
\hline 3 & Split - Skalice & & Oct 2009 & Adult \\
\cline { 2 - 5 } & & Cro1, HQ906848 (2) & Adult \\
\hline 4 & Split - Gripe & Cro2, HQ906849 (1) & Adult \\
\hline 5 & Split - Meje & Cro3, HQ 906850 (1) HQ906848 (2) & Adult \\
\hline 6 & Podstrana & Cro2, HQ906849 (2) & Sep 2009 & Adult \\
\hline 7 & Vis & Cro1, HQ906848 (2) & Sep 2009 & Adult \\
\hline 8 & Ston & Cro3, HQ 906850 (1) & Oct 2009 & Adult \\
\hline 9 & Montenegro & Cro1, HQ906848 (3) & Oct 2009 & Oct 2009 \\
\hline 10 & Budva & Cro1, HQ906848 (2) & & Egg \\
\hline 11 & Bar & Cro1, HQ906848 (5) & Oct 2009 & Egg \\
\hline
\end{tabular}

order to amplify mitochondrial $N A D H$ dehydrogenase 5 subunit (ND5) the following primers designed by Birungi \& Munstermann (2002) were used: 5'-TCCTTAGAATAAAATCCCGC-3' (ND5F) and 5' GTTTCTGCTTTAGTTCATTCTTC 3' (ND5R). Each PCR reaction was performed using the TaqMan Master Mix solution (Qiagen, Hilden, Germany) in a final reaction volume of $25 \mu \mathrm{l}$ containing $1 \mu \mathrm{M}$ of each primer (SigmaAldrich, Steinheim, Germany) and $2 \mu 1$ of template DNA. PCR reactions were conducted in a Mastercycler personal (Eppendorf, Hamburg, Germany) using, for COI, an initial denaturation step of $15 \mathrm{~min}$ at $95^{\circ} \mathrm{C}$ followed by 35 cycles of $94^{\circ} \mathrm{C}$ for $1 \mathrm{~min}, 50^{\circ} \mathrm{C}$ for $45 \mathrm{~s}$, and $72^{\circ} \mathrm{C}$ for $1 \mathrm{~min}$, and a final extension at $72^{\circ} \mathrm{C}$ for $10 \mathrm{~min}$. For $N D 5$, the PCR cycles consisted of an initial denaturation step at $95^{\circ} \mathrm{C}$ for $15 \mathrm{~min}$, followed by 30 cycles at $94^{\circ} \mathrm{C}$ for $30 \mathrm{~s}, 46^{\circ} \mathrm{C}$ for $45 \mathrm{~s}$, and $72^{\circ} \mathrm{C}$ for $1 \mathrm{~min}$, and a final extension at $72^{\circ} \mathrm{C}$ for $10 \mathrm{~min}$. The electrophoresis of the PCR products was done at $120 \mathrm{~V}$ on $1.5 \%$ agarose gel in TBE buffer with a 1000 bp DNA marker and afterwards purified with QIAquick gel extraction kit (Qiagen) according to manufacturer's specifications. The PCR products were sent to Macrogen (Seoul, Korea) for sequencing. Sequences were submitted to GenBank.

\section{Data analysis}

Alignment was performed manually on DNA sequences using Se-Al v2.0a11 (Rambaut A. 1996). Se-Al: Sequence Alignment Editor available at http://evolve.zoo.ox.ac.uk/, for a final length of $318 \mathrm{bp}$ for $C O I$ and $369 \mathrm{bp}$ for ND5. Numbers of variable sites, fixed differences, haplotype (gene) and nucleotide diversity were determined using DnaSPv5 (Librado \& Rozas, 2009). Phylogenetic reconstructions were carried out using Bayesian inference with MrBayes 3.1.2 (Ronquist \& Huelsenbeck, 2003), with 4 chains of $1,000,000$ generations, trees sampled every 100 generations and burnin value set to $20 \%$ of the sampled trees. Sequences were analyzed using an evolutionary model designed for coding sequences taking the genetic code into account (Goldman \& Yang, 1994; Muse \& Gaunt, 1994; Shapiro et al.,
2006). Haplotype network was built from the same data and data from Table 3 using TCS (Clement et al., 2000).

\section{RESULTS}

\section{Genetic variability of Aedes albopictus along the East Adriatic coast}

All 39 samples collected along the East Adriatic coast and islands, from the North (Pula) to the South of the Adriatic region (Budva) (Fig. 1; Table 1), had a unique ND5 haplotype, H3 (named by Birungi \& Munstermann, 2002 and Mousson et al., 2005; Table 2). We deposited this 393 bp long sequence in GenBank under the accession number HQ906852.

COI sequences were also obtained for 39 individuals of A. albopictus (Fig. 1; Table 1). All sequences were 464 bp long. The total number of mutations was three. Two of them were parsimony informative and the third was a singleton. A total of four haplotypes were recorded. The haplotype (gene) diversity $(H d)$ in these specimens was very low $(0.282 \pm 0.091)$ and the corresponding nucleotide diversity $(\pi)$ was also very low $(0.000064 \pm 0.004)$ (Table 2). The most frequent COI haplotype, Crol (GenBank accession number HQ906848) was identified in 33 individuals collected at all 11 sampling sites along the entire East Adriatic coast and islands. Three individuals had the Cro2 haplotype (GenBank accession number HQ906849) and two the Cro3 haplotype (GenBank accession number HQ906850). A single individual had the Cro4 haplotype (GenBank accession number HQ906851) (Fig 1; Table 1). Our results indicate that the Tajima's $D$ value $(-1.2758)$ and $F u$ 's $F s$ statistics $(-2.216)$ for $C O I$ for the entire sample are both negative but not statistically significant $(P>0.10)$. These results signify an excess of 
TABLE 2. Variation in the sequences of COI and ND5 of specimens of Aedes albopictus from the East Adriatic coast and islands and haplotypes retrieved from GenBank, including haplotypes recorded in this study.

\begin{tabular}{|c|c|c|c|c|}
\hline & \multicolumn{2}{|l|}{ COI } & \multicolumn{2}{|c|}{ ND5 } \\
\hline & $\begin{array}{l}\text { Croatia and Montenegro } \\
\text { (sequences) }\end{array}$ & $\begin{array}{c}\text { GenBank } \\
\text { (haplotypes) }\end{array}$ & $\begin{array}{l}\text { Croatia and Montenegro } \\
\text { (sequences) }\end{array}$ & $\begin{array}{c}\text { GenBank } \\
\text { (haplotypes) }\end{array}$ \\
\hline Number of sequences/haplotypes & 39 & 26 & 39 & 27 \\
\hline Number of sites & 464 & 318 & 393 & 369 \\
\hline Variable sites & 3 & 8 & 0 & 11 \\
\hline Singleton variable sites & 1 & 7 & 0 & 8 \\
\hline Parsimony informative sites & 2 & 1 & 0 & 3 \\
\hline $\mathrm{G}+\mathrm{C}$ content & 0.334 & 0.357 & 0.212 & 0.226 \\
\hline No. of haplotypes & 4 & 9 & 1 & 10 \\
\hline Haplotype diversity: $H d \pm \mathrm{sd}$ & $0.282 \pm 0.091$ & $0.751 \pm 0.062$ & 0.00 & $0.721 \pm 0.088$ \\
\hline Nucleotide diversity: $\pi \pm$ sd & $0.00064 \pm 0.00022$ & $0.00333 \pm 0.00051$ & 0.00 & $0.00328 \pm 0.00081$ \\
\hline
\end{tabular}

low frequency polymorphisms, confirming a recent expansion in population size (Tajima, 1989).

\section{Phylogenetic relationships between $\mathrm{COI}$ and $\mathrm{ND5}$ haplotypes}

In order to identify the geographic origin of populations that colonized Croatia, we performed phylogenetic analyses of ND5 and COI haplotypes from Croatian populations and other Aedes albopictus haplotypes retrieved from GenBank. The analysis of these data revealed 9 haplotypes of $C O I$ and 10 of ND5 with a low gene diversity value (Table 2 ). The analysis of these data showed that there were very few variations in COI (1 parsimony-informative site) and ND5 (3 parsimonyinformative sites). COI haplotypes were divided into 9 groups denoted as HC1-HC9 (Table 3). The most frequent Croatian COI haplotype Cro1 (HQ906848) belongs to the $\mathrm{HCl}$ haplotype, whereas the second most frequent Croatian haplotype Cro2 (HQ906849) belongs to the HC2 haplotype. Two of the COI haplotypes: $\mathrm{H} 3$ and $\mathrm{H} 4$, are new.

The ND5 phylogenetic tree revealed two well supported clades (posterior probabilities (pp) of 0.98) one containing all the Brazilian haplotypes and the other the American, European, African and South-Asian haplotypes (Fig. 2). The COI phylogenetic trees also revealed two weakly supported clades (pp of 0.59 ), where three Croatian haplotypes, including the most frequent Cro1 haplotype (HQ906848), clustered with other European and American haplotypes. However the fourth Croatian COI haplotype, Cro2 (HQ906849), was the only European haplotype that clustered into a separate clade together with Indian, Brasilian and South-Asian haplotypes (Fig. 3). The haplotype network illustrating relationships among nine $C O I$ haplogroups is shown in Fig. 4. The majority of the A. albopictus haplotypes clustered into two distinct groups $\mathrm{HC} 1$ and $\mathrm{HC} 2$ distinguished by a single mutation at nucleotide position 36 (Table 4). These two haplogroups formed an internal node in each grouping with immediate derivative(s) separated by a single mutation (Fig. 4).

\section{DISCUSSION}

In contrast to the high levels of allozyme variation within populations of Asian tiger mosquito, Aedes albopictus, documented by several independent studies (Black et al., 1988, Kambhampati et al., 1991, Urbanelli et al., 2000), the level of mtDNA variation based on molecular markers such as $C y t b, C O I$ and ND5, is notably low (Kambhampati \& Rai, 1991; Birungi \& Munsterman,

TABLE 3. Haplotype frequency and classification of populations of Aedes albopictus into 9 COI groups.

\begin{tabular}{cccc}
\hline $\begin{array}{c}\text { COI } \\
\text { groups }\end{array}$ & Populations & $\begin{array}{c}\text { Frequency/no. } \\
\text { of individuals }\end{array}$ & $\begin{array}{c}\text { Sample } \\
\text { size }\end{array}$ \\
\hline & HQ906848_Croatia_Spl & $0.85 / 33$ & 39 \\
& AY748238_Greece_Thes & $0.95 / 19$ & 20 \\
& AY748239_Greece_Corf & $0.05 / 1$ & 20 \\
& AJ971008_France_Mont & $0.077 / 1$ & 13 \\
HC1 & AJ971013_Reunion_La & $0.077 / 1$ & 13 \\
& AJ971007_Madagascar & $0.077 / 1$ & 13 \\
& AJ971005_USA_Jackson & $0.077 / 1$ & 13 \\
& AJ9971009_France_Nain & $0.077 / 1$ & 13 \\
& AJ971011_USA_Hawaii & $0.077 / 1$ & 13 \\
\hline & HQ906849_Croatia_Spl & $0.08 / 3$ & 39 \\
& AY834241_India_Karna & $0.25 / 1$ & 4 \\
& AY729984_India_Pondi & $0.25 / 1$ & 4 \\
& DQ424959_India_Vihr & $0.25 / 1$ & 4 \\
HC2 & FJ372983_India_Thiru & $1.00 / 1$ & 1 \\
& AY971003_Brazil_Repr & $0.077 / 1$ & 13 \\
& AJ971010_Viet_Nam_Nh & $0.077 / 1$ & 13 \\
& AJ971014_Brazil_Sao & $0.077 / 1$ & 13 \\
& AJ971004_Viet_Nam_Ha & $0.077 / 1$ & 13 \\
& AJ971015_Thailand_Ch & $0.077 / 1$ & 13 \\
\hline HC3 & HQ906850_Croatia_Spl & $0.05 / 2$ & 39 \\
\hline HC4 & HQ906851_Croatia_Pul & $0.026 / 1$ & 39 \\
\hline HC5 & AY072044_Taiwan_Taip & $1.00 / 1$ & 1 \\
\hline HC6 & EU259306_India_Manan & $1.00 / 1$ & 1 \\
\hline HC7 & DQ310142_India_Sahar & $0.25 / 1$ & 4 \\
\hline HC8 & AJ971012_Reunion_La & $0.077 / 1$ & 13 \\
\hline HC9 & AJ971006_Cambodia_Se & $0.077 / 1$ & 13 \\
\hline & &
\end{tabular}

Haplotype data for populations from the native range; United States, Brazil, Madagascar and France, was obtained from Mousson et al. (2005). Haplotype data for populations from Greece was obtained from Patsoula et al. (2006) and from India from Kumar et al. (2007). 


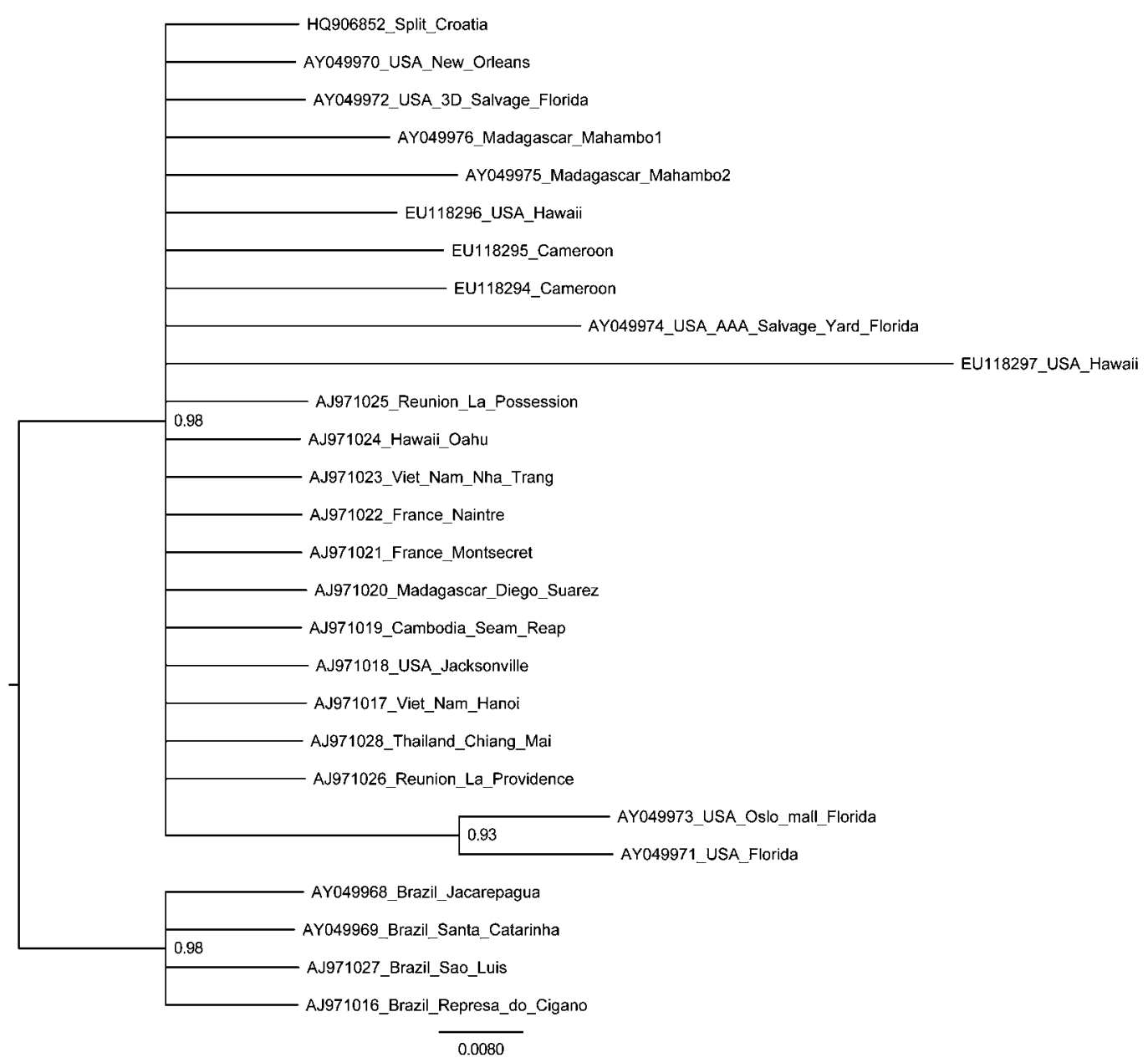

Fig. 2. Phylogenetic tree of Aedes albopictus ND5 haplotypes constructed using Bayesian inference. Numbers on nodes are posterior probabilities. Scale indicates expected number of substitutions per site.

2002; Mousson et al., 2005; Usmani-Brown et al., 2009; Maia et al., 2009; this study).

The observed pattern of genetic variation in populations of $A$. albopictus (high variation in the nuclear loci and low variation in mtDNA), which spread outside its native range, may be due to the small size of the founding populations, where genetic drift has had insufficient time to reduce the variation at nuclear loci and populations successively expanded and a few founder females became established in new geographic areas (Birungi \& Munstermann, 2002). Reduced levels of genetic variation could also be the consequence of extensive insect control measures, which involve source reduction and insecticide application leading to the reduction or even the eradication of A. albopictus populations (Birungi \& Munstermann, 2002; Usmani-Brown et al., 2009).

Mousson et al. (2005) compared the variability in three mitochondrial markers (Cytb, COI and ND5) in 13 speci-

TABLE 4. Differences in the nucleotide sequences of the haplotypes of the mtDNA cytochrome oxidase 1 (COI) gene of $A$. albopictus collected at locations along East-Adriatic coast.

\begin{tabular}{ccccccccc}
\hline \multirow{2}{*}{ COI haplotype } & \multicolumn{7}{c}{ Nucleotide position* } \\
\cline { 2 - 9 } & 18 & 19 & $\mathbf{3 6}$ & 79 & 102 & 180 & 198 & 318 \\
\hline HC1 & G & T & C & G & G & T & G & G \\
HC2 & - & - & T & - & - & - & - & - \\
HC3 & - & - & T & - & - & - & A & - \\
HC4 & - & - & T & - & - & - & - & A \\
HC5 & - & - & T & - & - & C & - & - \\
HC6 & - & - & - & A & - & - & - & - \\
HC7 & - & G & - & - & - & - & - & - \\
HC8 & A & - & T & - & - & - & - & - \\
HC9 & - & - & - & - & A & - & - & -
\end{tabular}

* Nucleotide position corresponding to the A. albopictus COI sequence in GenBank accession no. HQ906849; hyphens (-) denote nucleotide identity with haplotype $\mathrm{HC} 1$. 


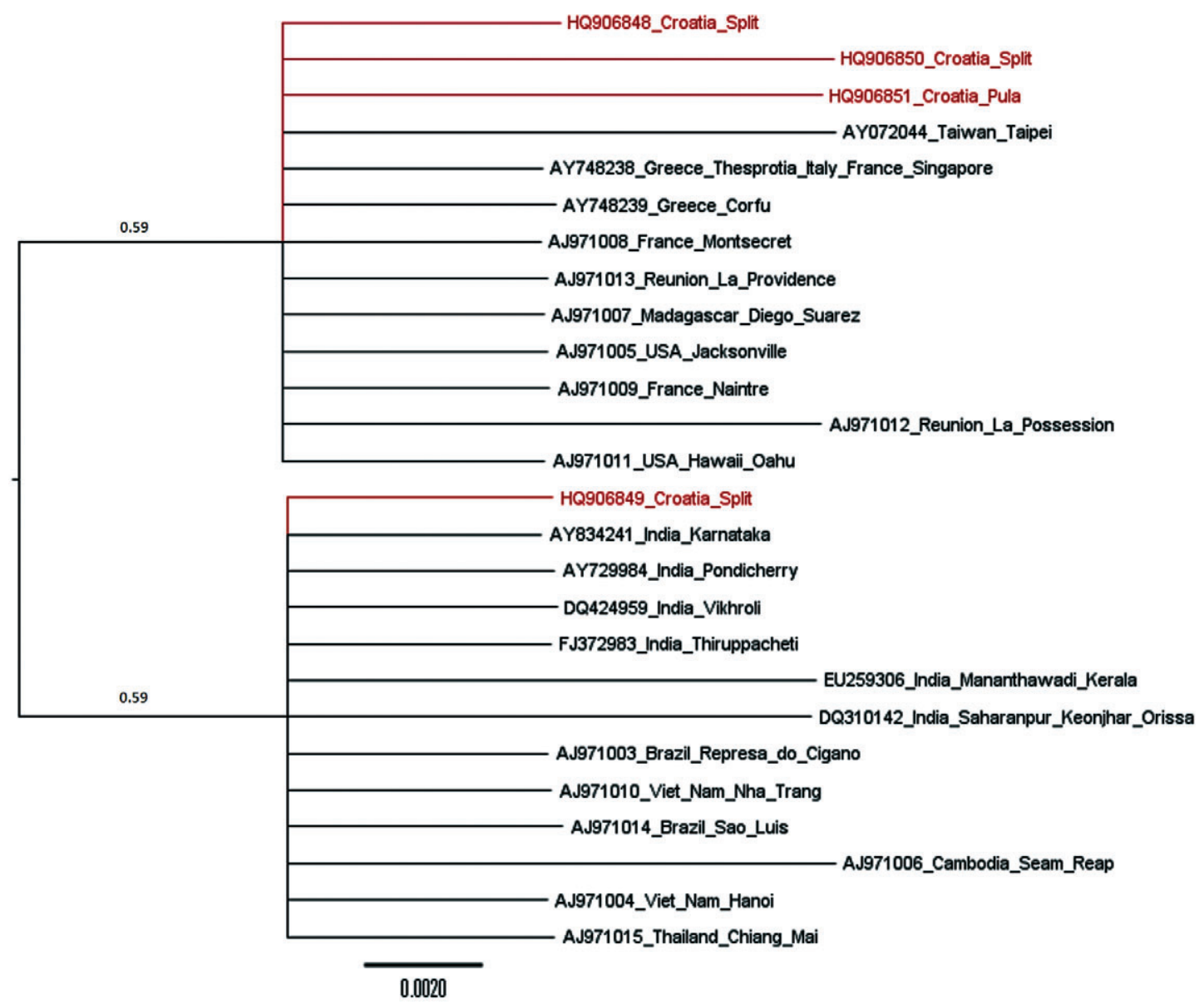

Fig. 3. Phylogenetic tree of Aedes albopictus based on COI and constructed using Bayesian inference. Numbers on nodes are posterior probabilities. Scale indicates expected number of substitutions per site.

mens of $A$. albopictus and concluded that $C y t b$ was more variable and useful than $C O I$ and $N D 5$. Our comparison of the sequence variability in COI and ND5 markers based on 39 specimens of $A$. albopictus collected along the East Adriatic coast confirmed the overall low level of sequence divergence in these two genes. However, in our study, COI was more informative as a molecular marker

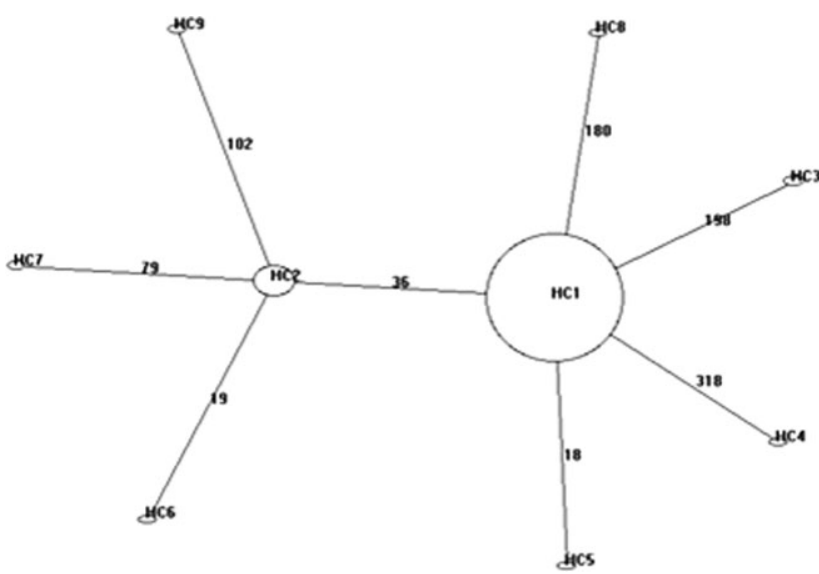

Fig. 4. Network of the COI haplotypes of Aedes albopictus generated using data from Table 3. The size of the ovals is proportional to the haplotype frequency. The number on line indicates the position of a single base substitution. than ND5 and revealed that there are four COI haplotypes but only one ND5 haplotype.

Usmani-Brown et al. (2009) and Birungi \& Munstermann (2002) combined all the available ND5 haplotypes into 13 groups consisting of 13 different haplotypes, $\mathrm{H} 1-\mathrm{H} 13$. The two most frequent haplotypes were $\mathrm{H} 1$ and $\mathrm{H} 3$, which differ in a single C-T substitution. The most frequent ND5 haplotype, $\mathrm{H} 3$, has been identified in the species' native range; continental United States, Hawaii, Madagascar, Cameroon, and Italy (Birungi \& Munsterman 2002; Usmani-Brown et al., 2009; Maia et al., 2009). The populations of $A$. albopictus from Croatia and Montenegro analyzed in this study also belong to this haplotype. The second largest group, containing haplotype $\mathrm{H} 1$, contained only the Brazilian populations. Our phylogenetic analysis thus confirmed earlier studies indicating a separate introduction of this species into Brazil (Birungi \& Munsterman, 2002, Usmani-Brown et al., 2009, Maia et al., 2009).

Similarly, we grouped all available $C O I$ sequences into 9 groups consisting of 9 COI haplotypes, $\mathrm{HC} 1-\mathrm{HC} 9$ (Table 3 ). The most frequent haplotypes are $\mathrm{HCl}$ and $\mathrm{HC} 2$, which differ by a single C-T transition at position 36 according to our input file (Table 4). The most frequent $\mathrm{COI}$ group $\mathrm{HC} 1$ includes European and American haplotypes, while the $\mathrm{HC} 2$ group includes native range (Indian and South-Asian) and Brazilian haplotypes. The 
majority of specimens analyzed in this study and in a study of a Greek population (Patsoula et al., 2006) belong to the HC1 haplogroup, but we also found that three of the individuals collected at Split belong to the HC2 haplotype. This finding, and the two new previously unidentified $\mathrm{COI}$ haplotypes (HC3 and $\mathrm{HC} 4$ ), indicate that there are at least four $A$. albopictus haplotypes in Croatia (Table 3).

Such data might suggest that the populations of $A$. albopictus that colonized the East Adriatic coast of Croatia probably did not originate from a single source population. Instead, it is likely there were several source populations and introductions. At least two independent introductions are reported in neighbouring regions of Croatia: in Albania, the first European case of an $A$. albopictus infestation was reported in 1979 and probably arrived in tires imported from China (Adhami \& Reiter, 1998); in Italy (Genoa and Veneto regions) this mosquito probably came in tires imported from the United States (Sabatini et al., 1990; Dalla Pozza \& Majori, 1992; Dalla Pozza et al., 1994). Split has two harbours for international maritime transport and is also an important destination for tourists during summer when a large number of Italian tourists visit the Croatian coast. Further investigations should focus on the monitoring of A. albopictus in Croatia and neighbouring countries. Because of the rather small variation in mtDNA sequences, analyses using more variable neutral nuclear markers, such as microsatellites, along with a more extensive sampling of populations not only in this region but also in the native range are needed in order to obtain a better understanding of the biology and immigration patterns of this potentially dangerous invasive species.

ACKNOWLEDGEMENT. We thank Z. Ikica, Institute of Marine Biology, Laboratory of Ichthyology and Marine Fisheries, Kotor, Montenegro. J.P. was funded by the Croatian Ministry of Science, Education and Sport (No. 177-11911196-0829).

\section{REFERENCES}

Adhami J. \& Reiter P. 1998: Introduction and establishment of Aedes (Stegomyia) albopictus Skuse (Diptera: Culicidae) in Albania. J. Am. Mosq. Control. Assoc. 14: 340-343.

Becker N., Petrić D., Zgomba M., Boase C., Dahl C., Lane J. \& KAISER A. 2003: Mosquitoes and their Control. Kluwer Academic / Plenum, New York, Boston, Dordrecht, London, Moscow, 498 pp.

Beltrame A., Angheben A., Bisoffi Z., Monteiro G., Marocco S., Calleri G., Lipani F., Gobbi F., Canta F. \& Castelli F. 2007: Imported chikungunya infection, Italy. Emerg. Infect. Dis. 8: 1264-1266

Birungi J. \& Munstermann L.E. 2002: Genetic structure of Aedes albopictus (Diptera: Cullicidae) populations based on mitochondrial ND5 sequences: Evidences for an independent invasions into Brasil and United States. Ann. Entomol. Soc. Am. 95: 125-132.

Black IV W.C., Ferrari J.A., Rai K.S. \& Sprenger D. 1988: Breeding structure of a colonizing species Aedes albopictus (Skuse) in the United States. Heredity 60: 173-181.
Clement M., Posada D. \& Crandall K.A. 2000: TCS: a computer program to estimate gene genealogies. Mol. Ecol. 9: $1657-1659$.

[CDC] Centers for Disease Control and Prevention 2005: Information on Aedes albopictus. http://www.cdc.gov/ncidod/ dvbid/Arbor/albopic_new.htm. Accesed 10 Nov. 2010.

Cuéllar-Jiménez M.E., Velásquez Eescobar O.L., GonzálezObando R. \& Morales-Reichmann C.A. 2007: Detectión de Aedes albopictus (Skuse) (Diptera: Culicidae) en la ciudad de Cali, Valle del Cauca, Colombia. Biomédica 27: 273-279.

Dalla Pozza G.L. \& Majori G. 1992: First record of Aedes albopictus establishment in Italy. J. Am. Mosq. Control. Assoc. 8: 318-320.

Dalla Pozza G.L., Romi R. \& Severini C. 1994: Source and spread of Aedes albopictus in the Veneto region of Italy. $J$. Am. Mosq. Control. Assoc. 10: 589-592.

[ECDC] European Centre for Disease Prevention and Control 2008: Development of Aedes albopictus risk maps. Tehnical report. http://ecdc.europa.eu/en/publications/Publications/ 0905_TER_Development_of_Aedes_Albopictus_Risk_Maps. pdf. Accesed 10 Nov 2010.

Flacio E., LÜthy P., Patocchi N., Guidotti F., Tonolla M. \& Peduzzi R. 2004: Primo ritrovamento di Aedes albopictus in Svizzera. Boll. Soc. Ticinese Sci. Natl. 92: 141-142.

Fontenille D. \& Toto J.C. 2001: Aedes (Stegomyia) albopictus (Skuse), a potential new Dengue vector in Southern Cameroon. Emerg. Infect. Dis. 7: 1066-1067.

Francy D.B., Karabatsos N., Wesson D.M., Moore C.G. JR, Lazuick J.S., Niebylski M.L., Tsai T.F. \& Craig G.B. JR 1990: A new arbovirus from Aedes albopictus, an Asian mosquito established in the United States. Science 250: $1738-1740$.

Gerhardt R.R., Gottfried K.L., Apperson C.S., Davis B.C., Erwin P.C., Smith A.B., Panella N.A., Powell E.E. \& Nasci R.S. 2001: First isolation of La Crosse virus from naturally infected Aedes albopictus. Emerg. Infect. Dis. 7: 807-811.

Goldman N. \& YANG Z. 1994: A codon-based model of nucleotide substitution for protein coding DNA sequences. Mol. Biol. Evol. 11: 725-736.

Gratz N.G. 2004: Critical review of the vector status of Aedes albopictus. Med. Vet. Entomol. 18: 215-227.

Haddad N., Harbach R.E., Chamat S. \& Bouharoun-Tayoun H. 2007: Presence of Aedes albopictus in Lebanon and Syria. J. Am. Mosq. Control. Assoc. 23: 226-228.

Hawley W.A. 1988: The biology of Aedes albopictus. J. Am. Mosq. Control. Assoc. 4: 1-39.

Hawley W.A., Reiter R., Copeland R.S., Pumpuni C.B. \& CRAIG G.B. JR 1987: Aedes albopictus in North America probable introduction in tires from northern Asia. Science 236: $1114-1116$.

KambHampati S. \& RaI K.S. 1991: Mitochondrial DNA variation within and among populations of the mosquito Aedes albopictus. Genome 34: 288-292.

Kambhampati S., Black IV W.C. \& Rai K.S. 1991: Geographic origin of United States and Brazilian populations of Aedes albopictus inferred from allozyme analysis. Heredity 67: 85-94.

Kumar N.P., Rajavel A.R., Natarajan R. \& Jambulingam P. 2007: DNA barcodes can distinguish species of Indian mosquitoes (Diptera: Culicidae). J. Med. Entomol. 44: 1-7.

Klobučar A., Merdić E., Benić N., Baklaić Z. \& Krčmar S. 2006: First record of Aedes albopictus in Croatia. J. Am. Mosq. Control. Assoc. 22: 147-148.

KNUDSEN A.B. 1995: Global distribution and continuing spread of Aedes albopictus. Parassitologia 37: 91-97. 
Krueger A. \& Hagen R.M. 2007: Short communication: First record of Aedes albopictus in Gabon, Central Africa. Trop. Med. Int. Health. 12: 1105-1107.

La Ruche G., Souarès Y., Armengaud A., Peloux-Petiot F., Delaunay P., Desprès P., Lenglet A., Jourdain F., LeparcGoffart I., Charlet F., Ollier L., Mantey K., Mollet T., Fournier JP., Torrents R., Leitmeyer K., Hilairet P., Zeller H., Van Bortel W., Dejour-Salamanca D., Grandadam M. \& Gastellu-Etchegorry M. 2010: First two autochthonous dengue virus infections in metropolitan France. Eurosurveillance 15: 39.

Librado P. \& Rozas J. 2009: DnaSP v5: A software for comprehensive analysis of DNA polymorphism data. Bioinformatics 25: $1451-1452$.

Madon M.B., Hazelrigg J.E., Shaw M.W., Kluh S. \& Mulla M.S. 2003: Has Aedes albopictus established in California? $J$. Am. Mosq. Control. Assoc. 19: 297-300.

Maia R.T., Scarpassa V.M., Maciel-Litaiff L.H. \& Tadei W.P. 2009: Reduced levels of genetic variation in Aedes albopictus (Diptera: Culicidae) from Manaus, Amazonas State, Brazil, based on analysis of the mitochondrial DNA ND5 gene. Genet. Mol. Res. 8: 998-1007.

Merdić E., Žıtro T., Jeličić Z. \& Klobučar A. 2009: Spreading of Aedes albopictus on Croatian islands by boats and yachts. Paper 5.1. Conference Programme and Abstract Book, 5th European Mosquito Control Association Workshop, Turin, Italy, 9-13th March 2009.

Mitchell C.J. 1995: Geographic spread of Aedes albopictus and potential for involvement in arbovirus cycles in the Mediterranean basin. J. Vector. Ecol. 20: 44-58.

Mitchell C.J., Niebylski M.L., Smith G.C., Karabatsos N., Martin D., Mutebi J.P., Craig G.B. JR \& Mahler M.J. 1992: Isolation of eastern equine encephalitis virus from Aedes albopictus in Florida. Science 257: 526-527.

Moore C.G. \& Mitchell C.J. 1997: Aedes albopictus in the United States: Ten-year presence and public health implications. Emerg. Infect. Dis. 3: 329-334.

Mousson L., Dauga C., Garrigues T., Schaffner F., Vazeille M. \& Failloux A.B. 2005: Phylogeography of Aedes (Stegomyia) aegypti (L.) and Aedes (Stegomyia) albopictus (Skuse) (Diptera: Culicidae) based on mitochondrial DNA variations. Genet. Res. 86: 1-11.

Muse S.V.B.S. \& GAuT B.S. 1994: A likelihood approach for comparing synonymous and nonsynonymous nucleotide substitution rates, with application to the chloroplast genome. Mol. Biol. Evol. 11: 715-724.

Patsoula E., Samanidou-Voyadjoglou A., Spanakos G., Kremastinou J., Nasioulas G. \& Vakalis N.C. 2006: Molecular and morphological characterization of Aedes albopictus in northwestern Greece and differentiation from Aedes cretinus and Aedes aegypti. J. Med. Entomol. 43: 40-54.

Pener H., Wilamowski A., Schnur H., Orshan L., Shalom U. \& Bear A. 2003: Aedes albopictus in Israel. Eur. Mosq. Bull. 14: 32 .

Pluskota B., Storch V., Braunbeck T., Beck M. \& Becker N. 2008: First record of Stegomyia albopicta (Skuse) (Diptera: Culicidae) in Germany. Eur. Mosq. Bull. 26: 1-5.
Reinert J.F. \& Harbach R.E. 2005: Generic changes affecting European aedine mosquitoes (Diptera: Culicidae: Aedini) with a checklist of species. Eur. Mosq. Bull. 19: 1-4.

ReITER P. 1998: Aedes albopictus and the world trade in used tires, 1988-1995: the shape of things to come? J. Am. Mosq. Control. Assoc. 14: 83-94.

Reiter P., Fontenille D. \& Paupy P. 2006: Aedes albopictus as an epidemic vector of chikungunya virus: another emerging problem? Lancet Infect. Dis. 8: 463-464.

Ritchie S.A., Moore P., Carruthers M., Williams C., Montgomery B., Foley P., Ahboo S., van den Hurk A.F., Lindsay M.D., Cooper B., Beebe N. \& Russell R.C. 2006: Discovery of a widespread infestation of Aedes albopictus in the Torres Strait, Australia. J. Am. Mosq. Control. Assoc. 22: 358-365.

Ronquist F. \& HuELSENBECK J.P. 2003: MRBAYES 3: Bayesian phylogenetic inference under mixed models. Bioinformatics 19: $1572-1574$

Rossi G.C., Pascual N.T. \& Krsticevic F.J. 1999: First record of Aedes albopictus (Skuse) from Argentina. J. Am. Mosq. Control. Assoc. 15: 422.

Sabatini A., Raineri V., Trovato G. \& Coluzzi M. 1990: Aedes albopictus in Italy and possible diffusion of the species into the Mediterranean area. Parassitologia 32: 301-304.

Schaffner F., Van Bortel W. \& Coosemans M. 2004: First record of Aedes (Stegomyia) albopictus in Belgium. J. Am. Mosq. Control. Assoc. 20: 201-203.

Schmidt-Chanasit J., Haditsch M., Schöneberg I., Günther S., Stark K. \& Frank C. 2010: Dengue virus infection in a traveler returning from Croatia to Germany. Eurosurveillance 15: 40.

Scholten E.J., Jacobs F., Linton Y.M., Dijkstra E., Fransen J. \& TAKKEN W. 2007: First record of Aedes (Stegomyia) albopictus in the Netherlands. Eur. Mosq. Bull. 22: 5-9.

Shapiro B., Rambaut A. \& Drummond A.J. 2006: Choosing appropriate substitution models for the phylogenetic analysis of protein-coding sequences. Mol. Biol. Evol. 23: 7-9.

Tалтма F. 1989: The effect of change in population size on DNA polymorphism. Genetics 123: 217-219.

Toto J.C., Abaga S., Carnevale P. \& Simard F. 2003: First report of the oriental mosquito Aedes albopictus on the West African island of Bioko, Equatorial Guinea. Med. Vet. Entomol. 17: 343-346.

Turell M.J., Sardelis M.R., Dohm D.J. \& O’Guinn M.L. 2001: Potential North American vectors of West Nile virus. Ann. N.Y. Acad. Sci. 951: 317-324.

Urbanelli S., Bellini R., Carrieri M., Sallicandro P. \& Celli G. 2000: Population structure of Aedes albopictus (Skuse): the mosquito which is colonizing Mediterranean countries. Heredity 84: 331-337.

Usmani-Brown S., Cohnstaedt L. \& Munstermann L.E. 2009: Population genetics of Aedes albopictus (Diptera: Culicidae) Invading populations, using mitochondrial nicotinamid adenine dinucleotide dehydrogenase subunit 5 sequence. Ann. Entomol. Soc. Am. 102: 144-150.

Received April 28, 2011; revised and accepted July 11, 2011 